\title{
Advances in catching fruit butterflies for quick inventory
}

\author{
Avanços na captura de borboletas frugívoras para inventário rápido
}

\author{
T. T. Maciel ${ }^{1 *}$; B. C. Barbosa ${ }^{1}$; H. H. Sanos-Prezoto ${ }^{1}$; J. A. K. Aguiar²; F. Prezoto ${ }^{1}$ \\ ${ }^{1}$ Laboratório de Ecologia Comportamental e Bioacústica - LABEC, Universidade Federal de Juiz de Fora. Campus \\ Universitário, Bairro Martelos, 36036-900 Juiz de Fora - MG, Brazil. \\ ${ }^{2}$ Laboratório de Análise de Glicoconjugados, Universidade Federal de Juiz de Fora, Juiz de Fora, \\ Minas Gerais, Brazil. \\ *tatitagliatti@hotmail.com
}

(Recebido em 15 de agosto de 2019; aceito em 20 de dezembro de 2019)

\begin{abstract}
The family Nymphalidae comprises frugivorous butterflies that are frequently used as bioindicators in environmental assessment studies. The collection of these lepidopterans is easily made with traps filled with fruit baits. The most frequently used bait is a mixture of banana and sugarcane juice, though other mixtures are also attractive. Hence, the objective of the present study was to assess the attractiveness and aging effect of baits used to capture fruit-feeding butterflies. All tested baits contained fructose, glucose, and sucrose but it was not possible to determine an optimal capture period in terms of bait aging, as sugar concentrations varied throughout the fermentation process.

Keywords: Lepidoptera, Nymphalidae, rapid ecological assessment.
\end{abstract}

A família Nymphalidae, representada pelas borboletas frugívoras é frequentemente usada como bioindicador em estudos de avaliação ambiental. A coleta desses lepidópteros é facilmente realizada por armadilhas atrativas com iscas de fruta fermentada, sendo uma mistura de banana com caldo de cana o princípio atrativo mais utilizado, contudo outras misturas também podem atuar como substâncias atrativas. Desta forma, o objetivo deste estudo foi avaliar a atratividade e o efeito de envelhecimento de iscas alimentares na captura de lepidópteros frugívoros. Todas as iscas testadas apresentaram os açúcares frutose, glicose e sacarose, contudo não foi possível determinar um período ótimo de captura quanto ao envelhecimento das iscas, já que as concentrações dos açúcares sofreram variação ao longo do processo de fermentação.

Palavras-chave: avaliação ecológica rápida, Lepidoptera, Nymphalidae.

\section{INTRODUCTION}

Fruit-feeding butterflies are frequently used as bioindicators of the environmental quality, as there is a relation between total species richness and changes in physical factors of the habitat, and because they also present a close relationship with plants [1,2,3]. In addition, these insects are easy to visualize, manipulate and identify [4]. Although long diversity studies are essential for knowledge of the fauna, they sometimes become unfeasible. For example, monitoring in hard-toreach areas is almost impossible on a weekly or even monthly basis. Rapid biological evaluations have alternatively been used in entomofauna surveys.

Among the methods for sampling lepidopterans, such as active (insect nets) or passive collection (traps) [5], we highlight Van Someren-Rydon attractive traps, which are used to collect fruitfeeding butterflies $[6,7,8]$ in several biomes $[9,10,11]$. Some advantages of collecting butterflies with attractive baits that justify their broad use in species inventories are their feasibility and low cost of capture, which are easily accomplished with fruit baits [12]. The most used bait is a mixture of banana and sugarcane juice $[10,11]$. Other blends, however, can also be attractive: other fruits, like pineapple, or even fish, shrimp and feces $[13,14,15]$.

Aiming at optimizing practical and reliable methods for assessing changes in biodiversity and ecosystem function, the study evaluated the attractiveness of different fruit baits in the field to capture frugivorous butterflies. It was also evaluated the composition of the bait on the types of sugar in the laboratory. 


\section{MATERIAL AND METHODS}

We carried out the present study in the Botanical Garden of the Federal University of Juiz de Fora (JB-UFJF), located in the municipality of Juiz de Fora, southeastern Minas Gerais State, at $750 \mathrm{~m}$ a.s.l. in an area of 84 ha $\left(21^{\circ} 43^{\prime} 28^{\prime \prime} \mathrm{S} ; 4^{\circ} 16^{\prime} 47^{\prime \prime} \mathrm{W}\right)$ [16]. The climate is warm subtropical with dry winter (Cwa), according to the Köppen-Geiger system [17]. The study was carried out from July 2013 to February 2014, in a total of six sampling events: three in the dry season (July, August and September) and three in the rainy season (October, January and February).

To sample the insects, we used nine modified Van Someren-Rydon traps. Based on the methods commonly used in inventories of fruit-feeding butterflies [10,13,18], we tested the following baits: pineapple with sugarcane juice $(P \& S)$, banana with sugarcane juice $(B \& S)$, and banana with water $(\mathrm{B} \& \mathrm{~W})$. All baits were prepared as juice, in a blender, at the proportion of three parts of mature fruit $(300 \mathrm{~g})$ to one part of liquid $(100 \mathrm{ml})$ and were stored in plastic containers and aged for $48 \mathrm{~h}$ at room temperature. We set up the traps at approximately $1.5 \mathrm{~m}$ above ground, and divided them in three sets. Each set comprised three traps, and each trap contained $200 \mathrm{ml}$ of a single type of bait. The traps were located $25 \mathrm{~m}$ apart from each other. The trap sets were $225 \mathrm{~m}$ apart from each other and remained in the field for $48 \mathrm{~h}$ during each sampling event, which makes a total sampling effort of $432 \mathrm{~h}$.

Small nymphalids were killed by thoracic compression and large ones were killed with an ethanol injection in the thorax, following Duarte et al. (2012) [5]. Specimens were identified using published keys $[6,13,18]$ and through comparison with specimens of the entomological collection of the Natural History Museum of the Academy of Commerce and of the Center of Higher Education of Juiz de Fora. The collected material was deposited in the Laboratory of Behavioral Ecology and Bioacoustics (LABEC) at UFJF; some individuals were dry-mounted to make a butterfly display case.

To estimate the sugar content of the baits, we measured reducing sugars (fructose and glucose) using the 3,5-dinitrosalicylic acid method (DNS). We analyzed baits after 48, 72, and $96 \mathrm{~h}$ of fermentation. For building the standard curve of glucose and fructose we prepared solutions of both sugars at concentrations of $20,40,60,80$, and $100 \mathrm{mg} / \mathrm{ml}$. Reading was made in a spectrophotometer with absorbance at $540 \mathrm{~nm}$.

For paper chromatography, $4 \mu \mathrm{l}$ of standard solution (glucose and fructose) and of each sample at a concentration of $1 \mathrm{mg} / \mathrm{ml}$ of carbohydrate (prepared by dilution based on the results of the DNS method) were applied on Whatman paper n.1 and submitted to descending chromatography in isobutyric acid: $\mathrm{NH} 4 \mathrm{OH} 1.25 \mathrm{M}(5: 3 \mathrm{v} / \mathrm{v})$. After 18-24 h the chromatogram was dried in an oven with heating and air circulation. Reducing products were revealed with silver nitrate in alkaline medium.

To test for variations in abundance and richness of nymphalids captured with different baits, we used a Kruskal-Wallis test using BioEstat 5.3, and for the dry and rainy periods we used Student's T-Test using Past 3.08.

\section{RESULTS AND DISCUSSION}

We collected 134 individual nymphalid butterflies of 28 species and 22 genera, which belonged to four subfamilies: Biblidinae $(\mathrm{N}=11)$, Satryinae $(\mathrm{N}=11)$, Charaxinae $(\mathrm{N}=5)$, and Nymphalinae $(\mathrm{N}=1)($ Table 1).

The baits behaved differently when we evaluated the catch species, Nica flavilla (Godart, 1824), Temenis laothoe (Cramer, 1777) and Eryphanis reevesii (Doubleday, 1849) were captured exclusively with pineapple with sugarcane juice. However, this bait did not attract the species Catonephele numilia (Cramer, 1775) and Memphis moruus (Prittwitz, 1865), which were captured with other baits. Dasyophthalma creusa (Hübner, [1821]) and Memphis appias (Hübner, [1825]) were captured exclusively with banana with water and Moneuptychia soter (Butler, 1877), Myscelia orsis (Drury, 1782), Biblis hyperia (Cramer, 1779), and Eteona tisiphone (Boisduval, 1836) with banana with sugarcane juice (Table 1).

Although they recorded exclusive species, there was no statistical difference between baits in relation to abundance $(\mathrm{B} \& \mathrm{~W} \times \mathrm{P} \& \mathrm{~S}: \mathrm{H}=0.7923, \mathrm{p}=0.3734 ; \mathrm{B} \& \mathrm{~W} \times \mathrm{B} \& \mathrm{~S}: \mathrm{H}=0.1691, \mathrm{p}=0.6809$; 
P\&S x B\&S: $\mathrm{H}=2.5913, \mathrm{p}=0.1075)$ and richness $(\mathrm{B} \& \mathrm{~W} \times \mathrm{P} \& \mathrm{~S}: \mathrm{H}=0.3243 ; \mathrm{p}=0.5690 ; \mathrm{B} \& \mathrm{~W}$ x B\&S: $\mathrm{H}=0.5916 ; \mathrm{p}=0.4418 ; \mathrm{P} \& \mathrm{~S} \times \mathrm{B} \& \mathrm{~S}: \mathrm{H}=1.4732 ; \mathrm{p}=0.2248)$.

There was also no significant difference between the dry and rainy periods in relation to abundance recorded by the different baits $(\mathrm{B} \& \mathrm{~W}: \mathrm{t}=0.4756, \mathrm{p}=0.3181 ; \mathrm{B} \& \mathrm{~S}: \mathrm{t}=1.5133, \mathrm{p}=$ $0.0687 ; \mathrm{P} \& \mathrm{~S}: \mathrm{t}=0.3656, \mathrm{p}=0.3581)$ and richness $(\mathrm{B} \& \mathrm{~W}: \mathrm{t}=0.0000, \mathrm{p}=0.5000 ; \mathrm{B} \& \mathrm{~S}: \mathrm{t}=-0.5317$, $\mathrm{p}=0.2985 ; \mathrm{P} \& \mathrm{~S}: \mathrm{t}=-0.2628, \mathrm{p}=0.3969)$.

Table 1. Spectrum and constancy of fruit-feeding Nymphalids captured with Van Someren-Rydon traps of different baits in the Botanical Garden of the Federal University of Juiz de Fora. Legend: B\&S = Banana and Sugarcane Juice, $B \& W=$ Banana and Water and $P \& S=$ Pineapple and Sugarcane Juice.

\begin{tabular}{|c|c|c|c|c|}
\hline \multirow{2}{*}{ Subfamily/Species } & \multicolumn{4}{|c|}{ Abundance } \\
\hline & $\mathbf{B} \& \mathbf{S}$ & $\mathbf{B} \& \mathbf{W}$ & P\&S & Total \\
\hline \multicolumn{5}{|l|}{ Biblidinae } \\
\hline Biblis hyperia (Cramer, 1779) & 1 & 0 & 0 & 1 \\
\hline Catonephele acontius (Linnaeus, 1771) & 3 & 3 & 4 & 10 \\
\hline Catonephele numilia (Cramer, 1775) & 1 & 1 & 0 & 2 \\
\hline Epiphile orea (Hübner, [1823]) & 1 & 1 & 2 & 4 \\
\hline Hamadryas amphinome (Linnaeus, 1767) & 1 & 0 & 2 & 3 \\
\hline Hamadryas arete (Doubleday, 1847) & 2 & 1 & 1 & 4 \\
\hline Hamadryas epinome (Felder \& Felder, 1867) & 0 & 2 & 2 & 4 \\
\hline Hamadryas feronia (Linnaeus, 1758) & 4 & 5 & 10 & 19 \\
\hline Myscelia orsis (Drury, 1782) & 1 & 0 & 0 & 1 \\
\hline Nica flavilla (Godart, 1824) & 0 & 0 & 1 & 1 \\
\hline Temenis laothoe (Cramer, [1777]) & 0 & 0 & 1 & 1 \\
\hline \multicolumn{5}{|l|}{ Satyrinae } \\
\hline Caligo brasiliensis (C. Felder, 1862) & 0 & 4 & 2 & 6 \\
\hline Dasyophthalma creusa (Hübner, [1821]) & 0 & 1 & 0 & 1 \\
\hline Eryphanis reevesii (Doubleday, 1849) & 0 & 0 & 1 & 1 \\
\hline Eteona tisiphone (Boisduval, 1836) & 1 & 0 & 0 & 1 \\
\hline Hermeuptychia hermes (Fabricius 1775) & 2 & 1 & 2 & 5 \\
\hline Moneuptychia soter (Butler, 1877) & 1 & 0 & 0 & 1 \\
\hline Morpho helenor (Cramer, 1776) & 0 & 1 & 2 & 3 \\
\hline Opsiphanes invirae (Huebner, 1818) & 3 & 1 & 4 & 8 \\
\hline Pareuptychia ocirrhoe (Fabricius, 1776) & 2 & 4 & 4 & 10 \\
\hline Taygetis laches (Fabricius, 1793) & 1 & 1 & 11 & 13 \\
\hline Taygetis virgilia (Cramer, 1776) & 2 & 0 & 2 & 4 \\
\hline \multicolumn{5}{|l|}{ Charaxinae } \\
\hline Archaeoprepona demophon (Linnaeus, 1758) & 0 & 3 & 1 & 4 \\
\hline Fountainea ryphea (Cramer, 1775) & 1 & 3 & 4 & 8 \\
\hline Hypna clytemnestra (Cramer, 1777) & 0 & 1 & 1 & 2 \\
\hline Memphis appias (Hübner, [1825]) & 0 & 1 & 0 & 1 \\
\hline Memphis moruus (Prittwitz, 1865 & 2 & 3 & 0 & 5 \\
\hline \multicolumn{5}{|l|}{ Nymphalinae } \\
\hline Colobura dirce (Linnaeus, 1758) & 4 & 5 & 2 & 11 \\
\hline Total of abundance & 33 & 42 & 59 & 134 \\
\hline Total of species & 18 & 19 & 20 & \\
\hline
\end{tabular}


All the baits contain fructose, glucose and sucrose according to the result obtained by the DNS method and confirmed by paper chromatography. Regarding to the concentration of reducing sugar was observed that $\mathrm{P} \& \mathrm{~S}$ and $\mathrm{B} \& \mathrm{~S}$ behaved as expected, that is, the concentration of reducing sugars increased with the progress of the fermentation process (Table 2). The water present in the bait $\mathrm{B} \& \mathrm{~W}$ may have reduced the fermentation process, so the concentration of reducing sugars remained low (Table 2).

Our results, corroborating those of Molleman et al. (2005) [14] and Freitas et al. (2014) [15], suggest that lepidopterans are attracted, not by the sugar, but by substances present in baits or released by fermentation (volatile).

Table 2. Reducing sugar content estimated with the DNS method at different fermentation levels.

\begin{tabular}{l|c|c|c}
\hline \hline \multicolumn{1}{c|}{ Mean mass $(\boldsymbol{\mu g})$} & $\mathbf{4 8} \mathbf{~ h}(\boldsymbol{\mu g})$ & $\mathbf{7 2} \mathbf{~ h ~}(\boldsymbol{\mu g})$ & $\mathbf{9 6} \mathbf{~ h}(\boldsymbol{\mu g})$ \\
\hline Pineapple + Sugarcane & 9.02 & 9.12 & 20.91 \\
Banana + Water & 5.06 & 6.1 & 5.25 \\
Banana + Sugarcane & 6 & 7.13 & 8.36 \\
\hline
\end{tabular}

\section{CONCLUSION}

In this study, the use of attractive traps proved to offer a useful way to monitor changes in species abundance over time, compare species composition and abundance between sites, and track individual movement. For a quick inventory, where the goal is to record the greatest diversity in the shortest time, we recommend a set of all three baits, at any time of year, as each one captures a different set of species and, if possible, a consortium with an active collection method for sampling be maximized.

\section{ACKNOWLEDGMENTS}

This work was supported by the Universidade Federal de Juiz de Fora (UFJF), the University of Otago, the Coordenação de Aperfeiçoamento de Pessoal de Nível Superior (CAPES), the Conselho de Desenvolvimento Cientifico e Tecnológico $(\mathrm{CNPq})$, and the Fundação de Amparo à Pesquisa do Estado de Minas Gerais (FAPEMIG).

\section{REFERÊNCIAS BIBLIOGRÁFICAS}

1. New TR. Are Lepidoptera an effective 'umbrella group' for biodiversity conservation? J Insect Conserv. 1997;1:5-12.

2. Mcgeoch, MA. The selection, testing and application of terrestrial insects as bioindicators. Biol Rev. 1998;73:181-201, doi: 10.1111/j.1469-185X.1997.tb00029.x.

3. Lima-Verde EPA, Hernández MIM. Sucessão ecológica em áreas reflorestadas de restingas: respostas da comunidade de borboletas Nymphalidae. Iniciados. 2007;12:13-22.

4. Mielke OHH, Casagrande MM. Papilionoidea e Hesperioidea (Lepidoptera) do Parque Estadual do Morro do Diabo, Teodoro Sampaio, São Paulo, Brasil. Rev Bras Biol. 1997;14:967-1001, doi: 10.1590/S010181751997000400013

5. Duarte M, Marconato G, Dpecht A, Casagrande MM. Insetos do Brasil: Diversidade e Taxonomia; 2012. Chapter 37, Lepidoptera; p. 625-682..

6. Devries PJ. The butterflies of Costa Rica and their natural history. Papilionidae, Pieridae, Nymphalidae. Princeton University Press, Princeton. 1987. 327 p.

7. Shuey JA. An optimized portable bait trap for quantitative sampling of butterflies. Trop Lepid. 1997;8(1):1-4.

8. Swaay CV, Regan E, Ling M, Bozhinovska E, Fernandez M, Marini-Filho UL. Guidelines for Standardised Global Butterfly Monitoring. Group on Earth Observations Biodiversity Observation Network, Leipzig, Germany. Geo Bon Technical Series 1. 201532 p.

9. Gozzi MR, Beirão MV, Medeiros LR, Neves FS, Fagundes M. Borboletas frugívoras em uma região de transição entre cerrado sensu stricto e caatinga no norte de Minas Gerais, Brasil. MG. BIOTA. 2011;4(5):25-37. 
10. Corso G, Hernández MIM. Borboletas frugívoras da Mata Atlântica no Parque Estadual da Serra do Tabuleiro, Santa Catarina, Brasil. Biotemas. 2012;25(4):139-148, doi: 10.5007/21757925.2012v25n4p139.

11. Silva ARM, Castro CO, Mafia PO, Mendonça MOC, Alves TCC, Beirão MV. Borboletas frugívoras (Lepidoptera: Nymphalidae) de uma área urbana (Área de Proteção Especial Manancial Cercadinho) em Belo Horizonte, Minas Gerais, Brasil. Biota Neotr. 2012;3(12):292-297, doi: 10.1590/S167606032012000300028.

12. Cullen JRL, Rudran R, Valladares-Padua C. Insetos como indicadores ambientais. 2003; Chapter 7, Métodos de estudos em biologia e manejo da vida silvestre; p. 125-151.

13. Uehara-Prado M, Freitas AVL, Francini RB, Brown JR KS. Guia das borboletas frugívoras da reserva estadual do morro grande e região de Caucaia do Alto, Cotia (São Paulo). Biota Neotr. 2004;4(1):1-23, doi: 10.1590/S1676-06032004000100007.

14. Molleman F, Van Alphen ME, Brakefield PM, Zwaan BJ. Preferences and food quality of fruit-feeding butterflies in Kibale Forest, Uganda. Biotropica. 2005;37(4):657-663, doi: 10.1111/j.17447429.2005.00083.

15. Freitas AVL, Iserhard CA, Santos JP, Carreira JYO, Ribeiro DB, Melo DHA, Rosa AHB, Marini Filho OJ, Accacio GM, Uehara-Prado M. Studies with butterfly bait traps: an overview. Rev Colomb Entomol. 2014;40:209-218.

16. Maciel TT, Barbosa BC. Áreas verdes urbanas: história, conceitos e importância ecológica. CES Rev. 2015;29(1):30-42.

17. Sá Júnior A, Carvalho LG, Silva FF, Carvalho Alves M. Application of the Köppen classification for climatic zoning in the state of Minas Gerais, Brazil. Theor Appl Clim. 2012;108:1-7.

18. Silva ARM, Guimarães MPM, Vitalino RF, Bagni AS, Martins YE, Cordeiro, AM, Oliveira, EG. Borboletas frugívoras do Parque Estadual do Rio Doce/MG. MG. BIOTA 2010;3(4):5-21. 